НАУКОВИЙ ВІСНИК

Scientific messenger of Lviv National University of
Veterimary Medicicie and Biotechnologies

(5)

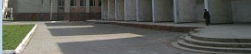

СЕРя: ВЕТЕРИнАРН НАУКИ

RIES: VETERINARY SCIENC
Науковий вісник Дьвівського національного університету ветеринарної медицини та біотехнологій імені С.3. Гжицького. Серія: Ветеринарні науки

Scientific Messenger of Lviv National University of Veterinary Medicine and Biotechnologies. Series: Veterinary sciences

UDC 636.2:612.467:591.132.5:591.436

\title{
Protein-synthesizing, bile-forming, urea-forming and carbohydrate functions in cows with fatty degeneration of the liver
}

V. V. Vlizlo ${ }^{1,2}$, O. I. Prystupa ${ }^{1}$, L. G. Slivinska ${ }^{1}$, Shan $\mathrm{Hu}^{2}$, R. V. Voloshyn ${ }^{1}$, B. V. Gutyj ${ }^{1}$, I. A. Maksymovych ${ }^{1}$, A. R. Shcherbatyy ${ }^{1}$, M. G. Lychuk ${ }^{1}$, B. O. Chernushkin ${ }^{1}$, M. I. Leno ${ }^{1}$, V. I. Rusyn ${ }^{1}$, M. P. Drach ${ }^{1}$, V. L. Fedorovych ${ }^{1}$, H. O. Zinko ${ }^{1}$, V. Y. Yaremchuk ${ }^{1}$

${ }^{I}$ Stepan Gzhytskyi National University of Veterinary Medicine and Biotechnologies, Lviv, Ukraine

${ }^{2}$ Agricultural University Qingdao, China

Article info

Received 27.09.2021

Received in revised form 27.10.2021

Accepted 28.10.2021

Stepan Gzhytskyi National University of Veterinary Medicine and Biotechnologies Lviv, Pekarska Str., 50, Lviv, 79010, Ukraine. Tel.: +38-032-239-26-32 E-mail:vasyl.vlizlo@lvet.edu.ua

Agricultural University Qingdao, Chengyang District, 266000, China.
Vlizlo, V. V., Prystupa, O. I., Slivinska, L. G., Hu, Shan, Voloshyn, R. V., Gutyj, B. V., Maksymovych, I. A., Shcherbatyy, A. R., Lychuk, M. G., Chernushkin, B. O., Leno, M. I., Rusyn, V. I., Drach, M. P., Fedorovych, V. L., Zinko, H. O., \& Yaremchuk, V. Y. (2021). Influence of probiotic additive "Evitalia" on growth and blood indices of quails. Scientific Messenger of Lviv National University of Veterinary Medicine and Biotechnologies. Series: Veterinary sciences, 23(104), 60-65. doi: $10.32718 /$ nvlvet10410

In dairy farms of Ukraine, where highly productive dairy cows are kept, liver lesions are often diagnosed in the postpartum period. Postmortem studies of the liver of cows that were forcibly slaughtered showed that in mostly animals were diagnosed with fatty degeneration of the liver. The main causes of fatty hepatosis were violations of the structure of rations, imbalance of feeding on essential nutrients and biologically active substances, low content of easily digestible carbohydrates and high protein content. The study was performed on cows aged 4-5 years with productivity for the previous lactation of 5.600-7.500 L of milk, in a winter-stall period of keeping, 2-3 weeks after calving. According to clinical and biochemical blood tests, two groups of cows were formed - 50 clinically healthy and 50 cows with fatty liver disease. In cows diagnosed with fatty liver degeneration, the disease was manifested by decreased productivity and fatness, loss of appetite, oppression, hypotony of the rumen, reticulum and omasum. In some cows, there was pain at the liver area, increasing boundaries of hepatic dullness, jaundice of the visible mucous membranes and sclera. The blood serum of all cows with fatty liver disease established a decrease in albumin content, indicating impaired protein synthesis function of the liver. In some cows, the content of total protein in the serum increased due to globulin fractions, mainly gamma globulins. The ratio between the content of albumins and globulins decreased, which indicates the development in the blood of sick animals dysproteinemia. The development of fatty infiltration of the liver caused an increase in the concentration of bile acids in the serum of all sick cows. This is due to reduced conjugation and excretion of cholates by affected hepatocytes from the bile capillaries. The formation, absorption, conjugation, and excretion of bilirubin in the bile is disturbed, which causes the accumulation of total and conjugated bilirubin in the serum of sick animals. The cholesterol content in the blood of cows decreased, caused a violation of the esterification of its esters by hepatocytes. The established changes in the content of bile acids, total and conjugated bilirubin, and cholesterol in the blood of sick cows indicate a violation of bile secretion, bile production, and cholestasis development. In some cows with fatty liver degeneration, urea formation function and carbohydrate function are impaired, leading to a decrease in blood urea content and glucose.

Key words: cows, fatty infiltration of the liver, symptoms, bile secretion and bile production, albumin, urea, glucose. 


\title{
Білоксинтезувальна, жовчоутворювальна, сечовиноутворювальна вуглеводна функції за жирового переродження печінки у корів
}

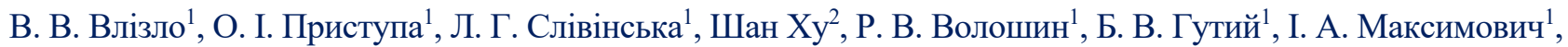 \\ А. Р. Щербатий ${ }^{1}$, М. Г. Личук ${ }^{1}$, Б. О. Чернушкін ${ }^{1}$, М. І. Леньо ${ }^{1}$, В. І. Русин ${ }^{1}$, М. П. Драч ${ }^{1}$, В. Л. Федорович${ }^{1}$, \\ Г. О. Зінько ${ }^{1}$, В. Ю. Яремчук ${ }^{1}$ \\ ${ }^{1}$ Львівський наиіональний університет ветеринарної медииини та біотехнологій імені С. 3. Гжицького, м. Львів, \\ Украӥна \\ ${ }_{2}^{2}$ Аграрний університет Ціндао, Китай
}

\begin{abstract}
У молочних господарствах України, де утримують високопродуктивних молочних корів, у післяродовий період часто діагностують ураження печінки. Посмертні дослідження печінки корів, які вимушено забивалися, показали, що в основному у тварин діагностувалося жирове переродження печінки. Основними причинами жирового гепатозу було порушення структури раціонів, незбалансованість годівлі за основними поживними та біологічно активними речовинами, низький вміст легкоперетравних вуглеводів і високий - протеїну. Дослідження проводили на коровах віком 4-5 років з продуктивністю за попередню лактацію 56007500 л молока, зимово-стійлового періоду утримання, 2-3 тижні після отелення. За результатами клінічних $і$ біохімічних досліджень крові було сформовано дві групи корів - 50 клінічно здорових і 50 хворих на жирову гепатодистрофіюо. У корів, в яких діагностували, жирове переродження печінки, хвороба проявлялася зниження продуктивності та вгодованості, порушення апетиту, пригніченням, гіпотонією передшлунків. У окремих корів встановлювали збільчення меж притуплення печінки, інколи болючість у ділянці печінки та жовтяничність видимих слизових оболонок і склери. У сироватці крові всіх хворих корів встановлено зниженням вмісту альбуміну, що свідчить про порушення білоксинтезувальної функиї̈ печінки. У частини корів у сироватиі крові зростав вміст загального білка, за рахунок глобулінових фракиій, переважно гамма-глобулінів. Співвіднотення між вмістом альбумінів $i$ глобулінів знижувалося, що вказує на розвиток у крові хворих диспротеїнемії. Розвиток жсирового переродження печінки спричиняв у сироватиі крові всіх хворих корів зростання концентрації жовчних кислот. Це є наслідком зниження кон 'югаиії та екскреції холатів ураженими гепатоцитами з жовчних капілярів. Порушується утворення, поглинання, кон'югація та виділення в жовч білірубіну, що призводило до накопичення загального та кон'югованого білірубіну у сироватчі крові хворих. Вміст холестеролу у крові корів знижувався, що вказує на порушення етерифікачії його ефірів гепаточитами. Встановлені у крові хворих зміни вмісту жовчних кислот, загального та кон'югованого білірубіну та холестеролу вказують на порушення жовчоутворення та жовчовиділення і розвиток холестазу. У частини корів, хворих на жирове переродження печінки, порушувалася сечовиноутворювальна та вуглеводна функції, що спричиняло зниження вмісту сечовини та глюкози у крові.
\end{abstract}

Ключові слова: корови, жирове переродження печінки, симптоми, жовчоутворення і жовчовиділення, альбумін, сечовина, глюкоза.

\section{Вступ}

Висока молочна продуктивність корів у господарствах значною мірою залежить від стану їх здоров'я. Середня тривалість продуктивного життя корів у країнах 3 високорозвинутим молочним скотарством становить в середньому 3-4 роки (Klug et al., 2004; Gruber \& Mansfeld, 2019). Це набагато коротше природної тривалості життя молочної худоби. Вибраковування корів у господарствах пов'язане зі зниженням їх молочної продуктивності, порушенням відтворювальної функції, що є наслідком розвитку різних патологій (De Vries \& Marcondes, 2020). Причиною захворюваності у молочних господарствах $є$ порушення технологічних процесів за утримання та годівлі високопродуктивних корів (Vlizo, 1998; Ingvartsen, 2006; Smith et al., 2017). Хвороби мають значне поширення у післяродовий період. Після отелення у молочних корів часто діагностують метаболічну патологію та ураження внутрішніх органів. Зокрема, захворювання печінки у корів займають провідне місце і вони зустрічаються набагато частіше, ніж прийнято вважати, оскільки патологія перебігає у субклінічній формі, або має загальні та неспецифічні симптоми (Bobe et al., 2004; Levchenko et al., 2012). Високопродуктивні корови часто хворіють на жирове переродження печінки, яке у науковій літературі ще називають жировий гепатоз, ожиріння печінки, жирова інфільтрація печі- нки, жирова гепатодистрофія (Dirksen et al., 2002; Kalaitzakis et al., 2010; Levchenko et al., 2012). Патологія спричиняє порушення основних функцій та структури печінки і метаболізму в цілому організмі, що призводить до зниження продуктивності, ураження інших життєво важливих органів і систем та передчасного вибракування високоудійних тварин (West, 1989; González et al., 2011).

У клітинах печінки синтезуються основні протеїни плазми крові, білірубін, жовчні кислоти, холестерол, відбуваються важливі процеси перетворення вуглеводів, знешкоджуються екзо- та ендотоксини, утворюється сечовина. Печінка регулює рівень утворених продуктів і виділення їх у кров та жовч (Levchenko et al., 2019). Проте, як показує аналіз літератури, стан основних функцій печінки за ії ураження часто залежать від селекції молочних порід, адаптації до нових умов утримання після завезення з-за кордону, особливостей годівлі (Vlizlo et al., 2020). Тому важливим $€$ аналіз функціонального стану печінки у корів у кожному господарстві, де діагностують захворювання.

Метою досліджень було вивчити стан білоксинтезувальної, сечовиноутворювальної, вуглеводної, жовчоутворювальної та жовчовидільної функцій печінки за жирового переродження печінки у корів. 


\section{Матеріал і методи досліджень}

Дослідження проводили на коровах віком 4-5 років 3 продуктивністю за попередню лактацію 5600 7500 л молока, зимово-стійлового періоду утримання, через 2-3 тижні після отелення. На початку експерименту за результатами клінічних і біохімічних досліджень крові сформовано дві групи корів - 50 клінічно здорових і 50 хворих на жирову гепатодистрофію. Під час клінічного дослідження особливу увагу звертали на колір склери, видимих слизових оболонок та непігментованих ділянок шкіри, а також болючість у ділянці печінки та їі збільшення.

Кров для досліджень відбирали з яремної вени вранці до годівлі. Функціональний стан печінки вивчали, досліджуючи показники крові, які характеризують білоксинтезувальну, сечовиноутворювальну, жовчоутворювальну, жовчовидільну, вуглеводну функції. Білоксинтезувальну функцію гепатоцитів вивчали за вмістом у сироватці крові загального протеїну (біуретовим методом) та його окремих фракцій електрофорезом у поліакриламідному гелі, вуглеводну - за концентрацією у крові глюкози (ензиматичним глюкозо-оксидазним методом), жовчоутворення та жовчовиділення - за вмістом у крові жовчних кислот (ферментативною реакцією тест-системою фірми “SENTINEL), загального холестеролу (метод Ілька), загального та кон'югованого білірубіну (метод Сндрашика і Грофа в модифікації Левченка і Влізла), сечовиноутворення - за вмістом сечовини у сироватці крові (реакцією з діацилмонооксидом) (Vlizlo et al., 2012).

Після вимушеного забою корів проводили ветеринарно-санітарне обстеження, звертаючи особливу увагу на структуру печінки.

Отримані цифрові дані опрацьовували статистично на персональному комп'ютері за допомогою програми Microsoft Office Excel, обчислюючи середнє арифметичне досліджуваної величини (М), похибку середнього арифметичного досліджуваної величини (m), коефіцієнт вірогідності різниць (р) між досліджуваними групами. Різницю вважали статистично вірогідною за $\mathrm{P}<0,05 ; 0,01$ та 0,001 .

\section{Результати та їх обговорення}

Обстеження та аналіз господарств, де проводилися дослідження, вказували на порушення менеджменту на фермах. Зокрема, для корів використовували цілорічну стійлову технологію утримання, без моціону і випасів. На фермах були відсутні окремі приміщення для сухостійних корів, основного дійного стада та родильне відділення.

У структурі раціону сухостійних корів у зимовий період утримання за обмінною енергією частка концентрованих кормів складала $11 \%$, грубих - $11 \%$, соковитих $-78 \%$. Енергоємність раціону забезпечувала потреби корів на 150,2 \% і становила 174,2 МДж. Кількість перетравного протеїну в раціоні сухостійних корів забезпечувала їх потребу на 106,4 \%, а цукру - на 73,3 \%. Цукрово-протеїнове співвідношення становило 0,6 до 1,0, за норми 0,8-1,2 до 1,0. Дефіцит цукру в раціоні сприяє посиленню глюконеогенезу та мобілізації жирів із депо і нагромадження їх у печінці (Ingvartsen, 2006; Smith et al., 2017). Крім цього, у раціоні сухостійних корів не вистачало сирої клітковини $(77,6 \%$ забезпеченості). Під час сухостійного періоду у частини корів реєстрували вищу вгодованість та ожиріння.

У раціоні післяродового періоду у дійних корів у розрахунку на обміну енергію переважали соковиті корми $75 \%$, частка грубих становила $2 \%$, а концентрованих - $23 \%$. Енергоємність раціону становила 125 МДж і забезпечувала потребу на $90 \%$. Вміст сухої речовини корму був вищим на $21,3 \%$. Водночас, забезпечення корів сирою клітковиною було досить низьким і складало 83,8 \%. Вміст перетравного протеїну забезпечував організм на 145,6 \%, кількість цукру в раціоні була низькою і становила $71 \%$ від потреби. Цукрово-протеїнове співвідношення було лише 0,5 до 1,0 , за потреби $0,8-1,2$, до 1,0 .

Інколи коровам згодовували у великій кількості кукурудзяну барду, яка при органолептичному дослідженні мала гнильний запах і була коричневого кольору.

Ветеринарно-санітарні обстеження корів, які вимушено забивалися, показали, що в основному у тварин діагностувалося жирове переродження печінки. Патологія реєструвалася у післяродовий період.

У корів, хворих на жирову інфільтрацію печінки, знижувалася молочна продуктивність, а також вгодованість (коефіцієнт вгодованості був від 1,5 до 3,0 ). У хворих загальний стан був пригніченим, встановлювали сухість та зниження еластичності шкіри, зниження апетиту, гіпотонію передшлунків. Видимі слизові оболонки були блідо-рожеві, рожеві або бліді. Жовтяничність видимих слизових оболонок та склери реєстрували в поодиноких корів. У окремих корів виявляли болючість у ділянці печінки та збільшення меж печінкового притуплення. Калові маси були сухуваті, у деяких корів покриті слизом, інколи спостерігали діарею. У частини хворих корів одночасно діагностували пододерматит, мастит, ендометрит. Враховуючи те, що симптоми ураження печінки $\epsilon$ загальними, а типові симптоми діагностуються в поодиноких випадках, тому для встановлення іiї патології важливим є проведення лабораторних досліджень крові (Kalaitzakis et al., 2010; Simonov \& Vlizlo, 2015).

Жирова інфільтрація гепатоцитів, а також їх відмирання внаслідок значного накопичення жирів спричиняе порушення основних функцій печінки. Однією 3 найважливіших функцій печінки є синтез протеїнів. Зокрема, альбуміни $100 \%$ утворюються у гепатоцитах. Нами встановлено, що у сироватці крові корів, хворих на жирове переродження печінки, знижувався вміст альбуміну як у абсолютному значенні (рис. 1), так і у відносному $(26,6 \pm 0,31 \%$, проти $42,4 \pm 0,30 \%$ у клінічно здорових, $\mathrm{P}<0,001)$ від всіх фракцій у загальному протеїні. Такі зміни альбуміну у крові свідчить про порушення білоксинтезувальної функції печінки, на що вказували й інші вчені (González et al., 2011; Chernushkin et al., 2020). Bpaxo- 
вуючи те, що альбуміни виконують важливі функції в організмі, зокрема підтримують колоїдно-осмотичний тиск крові, транспортують вуглеводи, ліпіди, гормони, вітаміни, мінеральні речовини, тому гіпоальбумінемія $€$ несприятливою інформативною клінікодіагностичною ознакою, яка свідчить про гостру та хронічну недостатність печінки (Levchenko et al., 2019).

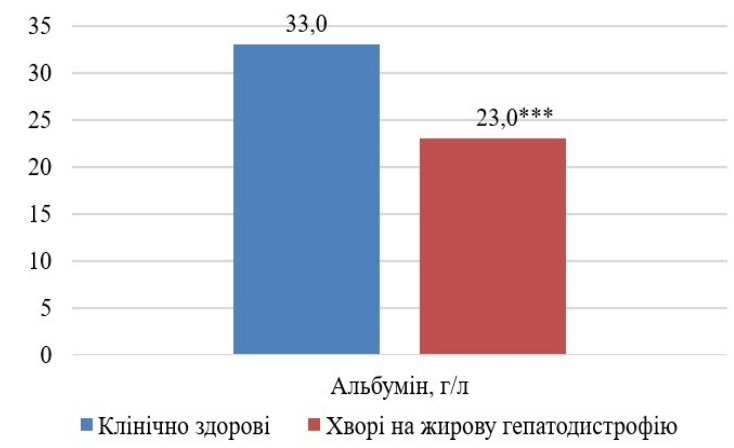

Рис. 1. Вміст альбуміна у сироватці крові корів

Незважаючи на зменшення вмісту альбуміну у сироватці крові, кількість загального протеїну у крові хворих корів зростала до 87,5 $\pm 0,34$ г/л $(\mathrm{P}<0,001)$ проти 77,7 $\pm 0,40$ г/л у клінічно здорових. Це відбувалося за рахунок зростання кількості альфа(P $<0,001)$, бета- $(\mathrm{P}<0,001)$ та гамма-глобулінових $(\mathrm{P}<0,001)$ фракцій. Накопичення вмісту глобулінів і зниження альбумінів у крові хворих корів спричиняло зниженням альбуміно-глобулінового коефіцієнта до $0,4 \pm 0,01(\mathrm{P}<0,001)$, проти $0,74 \pm 0,03$ у клінічно здорових, та розвиток диспротеїнемії. Надмірне утворення глобулінів в організмі корів, хворих на жирову гепатодистрофію, може пояснюватися подразненням імунокомпетентних клітин мононуклеарної системи (Morris et al., 2009).

Вміст сечовини у сироватці крові корів, хворих на жирову інфільтрацію печінки, був на 35 \% нижчим ( $\mathrm{P}<0,001)$, порівняно 3 клінічно здоровими (рис. 2). Слід відзначити, що сечовиноутворювальна функція гепатоцитів є досить стабільною, тому іiі порушення свідчить про значні зміни в паранхімі печінки. Зокрема, це встановлено у корів при тяжкому перебігу жирової гепатодистрофії із синдромами печінкової енцефалопатії та печінкової коми (Vlizlo, 1998).

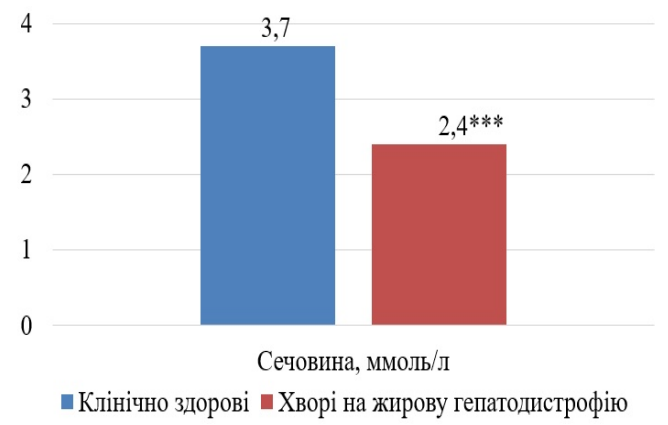

Рис. 2. Вміст сечовини у сироватці крові корів
Концентрація глюкози у крові хворих корів знижувалася у 1,6 раза $(\mathrm{P}<0,001)$ відносно клінічно здорових (рис. 3). Печінка $є$ основним органом, який забезпечує сталу концентрацію глюкози в крові завдяки процесам синтезу і розпаду глікогену та гліконеогенезу (Simonov et al., 2016). Встановлена нами гіпоглікемія у хворих на жирову гепатодистрофію корів сприяє активізації глікогенезу і утворення глюкози $з$ глікогену печінки і м'язів. Але глікогеноліз швидко згасає, оскільки за гіпоглікемії запасів глікогену вистачає лише на кілька днів (Van Knegsel et al., 2007). Організм намагається ліквідувати гіпоглікемію за рахунок глюконеогенезу. Гіперсекреція глюкокортикоїдів спричиняє мобілізацію жирів із депо, які потрапляючи у печінку, викликають жирову інфільтрацію гепатоцитів (Morris et al., 2009; Caixeta \& Omontese, 2021). Такі зміни в організмі корів є основними в патогенезі жирової дистрофії печінки.

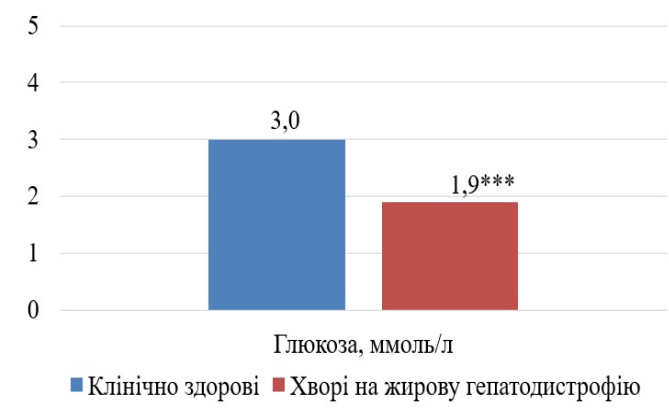

Рис. 3. Вміст глюкози у крові корів

У сироватці крові корів, хворих на жирове переродження печінки, концентрація жовчних кислот зростала у всіх тварин і була у 4,4 раза вищою $(\mathrm{P}<0,001)$, порівняно 3 клінічно здоровими (рис. 4). Незважаючи на те, що синтез жовчних кислот відбувається у печінці, однак їх вміст у крові зростає. Це можна пояснити зниження кон'югації та екскреції жовчних кислот гепатоцитами 3 жовчних капілярів у жовчні протоки (Rehage et al., 1999).

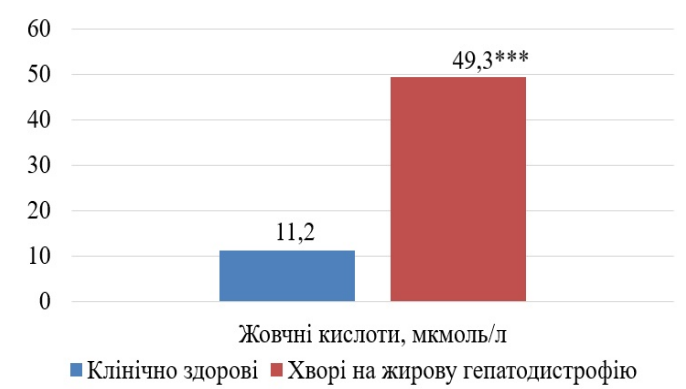

Рис. 4. Вміст жовчних кислот у сироватці крові корів

Подібні зміни встановлено і під час дослідження вмісту білірубіну в сироватці крові (рис. 5). Так, концентрація загального білірубіну в крові корів, хворих на гепатодистрофію, зростала у 4,2 рази $(\mathrm{P}<0,001)$, а кон'югованого - у 2,9 рази ( $\mathrm{P}<0,001)$, порівняно зі здоровими. Накопичення білірубіну в крові хворих свідчить про порушення його основних метаболічних процесів у печінці - утворення, поглинання, конюга- 
ція та виділення в жовч, що є характерним для жирового переродження печінки (Kalaitzakis et al., 2010).

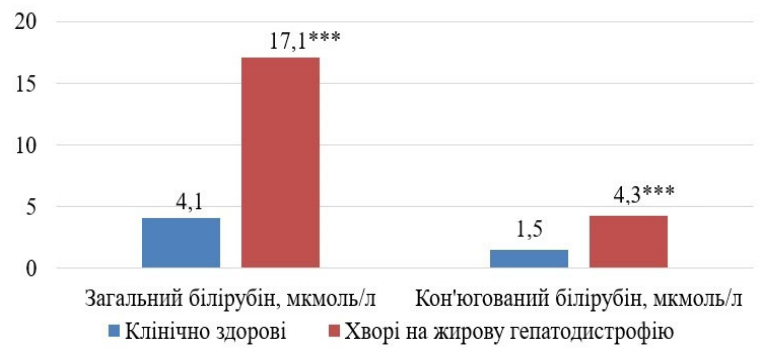

Рис. 5. Вміст загального та кон'югованого білірубіну у сироватці крові корів

Вміст холестеролу у сироватці крові хворих корів знижувався на $38 \%(\mathrm{P}<0,001)$, порівняно 3 клінічно здоровими (рис. 6).

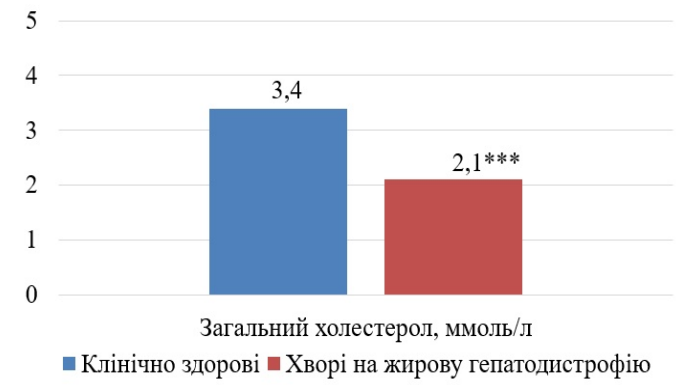

Рис. 6. Вміст холестеролу у сироватці крові корів

Зменшення концентрації холестеролу в сироватці крові може бути наслідком зниження етерифікації його ефірів гепатоцитами. Низький вміст холестеролу в крові $\epsilon$ характерною ознакою під час негативно енергетичного балансу (Gross et al., 2021), коли розвивається активна ліпомобілізація та жирова інфільтрація печінки. Гепатоцити виконують провідну роль у регуляції рівня і співвідношення вільного та етерифікованого холестеролу (Kraft \& Dürr, 2005). При захворюванні печінки порушується гепато-ентеральна циркуляція, зростає синтез жовчних кислот із холестеролу, що може бути теж причиною зниження рівня холестеролу в крові (Vlizlo \& Prystupa, 2011). Враховуючи те, що холестерол використовується для синтезу жовчних кислот, кортикостероїдних гормонів, вітаміну Д, входить до складу клітинних мембран, тому його дефіцит в організмі хворих корів можна розцінювати як один із патогенетичних факторів виникнення вторинних патологій (Yuskiv \& Vlizlo, 2014).

Таким чином, у крові корів, хворих на жирову гепатодистрофію, зростає вміст загального та кон'югованого білірубіну і жовчних кислот, але зменшується - холестеролу. Оскільки це $є$ основні компоненти жовчі, то це можна розцінювати як порушення жовчоутворення та жовчовиділення у хворих корів. Значна гіпербілірубінемія, яка була встановлена у окремих хворих корів, стала причиною жовтяничності слизових оболонок.

\section{Висновки}

1. У корів, хворих на жирове переродження печінки, характерним $\epsilon$ порушення протеїнсинтезувальної функції печінки, що характеризується зниження вмісту альбуміну у сироватці крові. При цьому, вміст загального протеїну зростає за рахунок глобулінових фракцій.

2. За жирового переродження печінки у сироватці крові корів знижується вміст загального холестеролу і зростає загального та кон'югованого білірубіну, а також жовчних кислот, що свідчить про порушення жовчоутворювальної та жовчовидільної функцій печінки.

3. У частини корів, хворих на жирове переродження печінки, у крові знижується вміст сечовини i концентрація глюкози, що можна розцінювати як порушення сечовиноутворювальної та вуглеводної функцій печінки.

Перспективи подальших досліджень. Будуть проведені дослідження високопродуктивних корів у різних господарствах України для встановлення поширення хвороб печінки та їх структури. Для цього планується провести гістологічне дослідження тканин печінки. Важливим буде проведення лабораторних досліджень сироватки крові на активність ензимів, зокрема гепатоспецифічних.

Відомості про конфлікт інтересів. Автори стверджують про відсутність конфлікту інтересів щодо їх вкладу та результатів досліджень.

\section{References}

Bobe, G., Young, J. W., \& Beitz, D. C. (2004). Invited review: Pathology, etiology, prevention, and treatment of fatty liver in dairy cows. J. Dairy Sci. 87(10), 3105-3124. doi: 10.3168/jds.S0022-0302(04)73446-3.

De Vries, A., \& Marcondes, M. I. (2020). Review: Overview of factors affecting productive lifespan of dairy cows. Animal, 14(1), 155-164. doi: $10.1017 /$ S1751731119003264.

Dirksen, G., Gründer, H. D., \& Stöber, M. (2002). Innere Medizin und Chirurgie des Rindes. Berlin: Parey, 1325.

Caixeta, L. S., \& Omontese, B. O. (2021). Monitoring and Improving the Metabolic Health of Dairy Cows during the Transition Period. Animals, 11(2), 352. doi: 10.3390/ani11020352.

Chernushkin, B. O., Vlizlo, V. V., Slivinska, L. G., Gutyj, B. V., Shcherbatyy, A. R., Maksymovych, I. A., Leno, M. I., Rusyn, V. I., Lychuk, M. H., Fedorovych, V. L., Lukashchuk, B. O., Zinko, H. O., \& Prystupa, O. I. (2020). Treatment strategies for sheep with acute yellow athrophy of the liver caused by the fasciolosis. Ukrainian Journal of Ecology, 10(2), 294-301. doi: $10.15421 / 2020100$.

González, F. D., Muiño, R., Pereira, V., Campos, R., \& Benedito, J. L. (2011). Relationship among blood indicators of lipomobilization and hepatic function 
during early lactation in high-yielding dairy cows. J. Vet Sci., 12(3), 251-255. doi: 10.4142/jvs.2011.12.3.251.

Gross, J. J., Schwinn, A.-C., Müller, E., Münger, A., Dohme-Meier, F., \& Bruckmaier, R. M. (2021). Plasma cholesterol levels and short-term adaptations of metabolism and milk production during feed restriction in early lactating dairy cows on pasture. J. Anim. Physiol. Anim. Nutr., 105(6), 1024-1033. doi: 10.1111/jpn.13531.

Gruber, S., \& Mansfeld, R. (2019). Herd health monitoring in dairy farms - discover metabolic diseases. An overview. Tierarztl. Prax. Ausg. G. Grosstiere Nutztiere, 47(4), 246-255. doi: 10.1055/a0949-1637.

Ingvartsen, K. L. (2006). Feeding- and management-related diseases in the transition cow - Physiological adaptations around calving and strategies to reduce feeding-related diseases. Animal Feed Science and Technology, 126(34), 175-213. doi: 10.1016/j.anifeedsci.2005.08.003.

Kalaitzakis, E., Panousis, N., \& Roubies, N. (2010). Clinicopathological evaluation of downer dairy cows with fatty liver. Can. Vet. J., 51(6). 615-622. URL: https://pubmed.ncbi.nlm.nih.gov/20808573.

Klug, F., Wangler, A., \& Rehbock, F. (2004). Aktuelle Probleme bei üter Milchkuh. LehmannsMedia. Berlin.

Kraft, W., \& Dürr, U. (2005). Klinische Labordiagnostik in der Tiermedizin. 6. Aufl. Stuttgart; New York : Schattauer, 157-161.

Levchenko, V. I., Kondrakhin, I. P., \& Vlizlo, V. V. (2012). Vnutrishni khvoroby tvaryn. Bila Tserkva (in Ukrainian).

Levchenko, V. I., Vlizlo, V. V., \& Kondrakhin, I. P. (2019). Klinichna diahnostyka khvorob tvaryn. Bila Tserkva (in Ukrainian).

Levchenko, V. I., Vlizlo, V. V., \& Kondrakhin, I. P. (2019). Veterynarna klinichna biokhimija. Bila Tserkva (in Ukrainian).

Morris, D. G., Waters, S. M., McCarthy, S. D., \& Patton, J. (2009). Pleiotropic effects of negative energy balance in the postpartum dairy cow on splenic gene expression: repercussions for innate and adaptive immunity. Physiol. Genomics, 39(1), 28-37. doi: 10.1152/physiolgenomics.90394.2008.

Rehage, J., Qualmann, K., \& Meier, C. (1999). Total serum bile acid concentrations in dairy cows with fatty liver and liver failure. Deut. Tierärztl Woch, 106, 2629. https://pubmed.ncbi.nlm.nih.gov/10028757.

Simonov, M., Vlizlo, V., \& Petruh, I. (2016). Plasma concentrations of insulin-like growth factor, triiodothyronine, thyroxine, and insulin in cows during different physiological states. Agricultural Science and Practice, 3(3), 17-21. doi: 10.15407/agrisp3.03.017.

Simonov, M., \& Vlizlo, V. (2015). Some blood markers of the functional state of liver in dairy cows with clinical ketosis. Bulg. J. Vet. Med., 18(1), 74-82. doi: $10.15547 /$ bjvm.814.

Smith, G. L., Friggens, N. C., Ashworth, C. J., \& Chagunda, M. G. G. (2017). Association between body energy content in the dry period and post-calving production disease status in dairy cattle. Animal, 11(9), 1590-1598. doi: 10.1017/S1751731117000040.

Van Knegsel, A. T. M., Van den Brand, H., \& Graat, E. A. M. (2007). Dietary energy source in dairy cows in early lactation: metabolites and metabolic hormones. J. Dairy Sci., 90(3). 1477-1485. doi: 10.3168/ jds.S0022-0302(07)71633-8.

Vlizlo, V. V. (1998). Lesions of the nervous system in liver pathology in cows (hepatic encephalopathy, hepatic coma). Veterynarna medyzyna, 74, 167-175.

Vlizlo, V. V. (2012). Laboratory methods of investigation in biology, stockbreeding and veterinary. Edited by V.V. Vlizlo. Lviv: SPOLOM (in Ukrainian).

Vlizo, V. V. (1998). The fat hepatosis of the hyghty productive cows. Manuscript. Kyiv.

Vlizlo, V. V., \& Prystupa, O. I. (2011). The state of biliary and biliary functions of the liver in cows with fatty hepatodystrophy. Naukovyi Visnyk veterynarnoi medyzyny. Bila Cerkwa, 8(87), 30-33.

Vlizlo, V. V., Simonov, M. P., Petruch, I. M. et al. (2020). Metabolic processes in the body of cows in the transit period and during the development of ketosis. Metodychni recomendazii. Lviv.

West, H. J. (1989). Liver function of dairy cows in late pregnancy and early lactation. Res. Vet. Sci., 46(2), 23123. URL: https://pubmed.ncbi.nlm.nih.gov/2704889.

Yuskiv, L. L., \& Vlizlo, V. V. (2014). Vitamin D Provision in High-Yield Dairy Cows during Winter Housing Period. Agricultural Science and Practice, 1(1), 42-46. doi: 10.15407/agrisp1.01.042. 